NBER WORKING PAPER SERIES

\title{
USING ONLINE PRICES FOR MEASURING REAL CONSUMPTION ACROSS COUNTRIES
}

\author{
Alberto Cavallo \\ W. Erwin Diewert \\ Robert C. Feenstra \\ Robert Inklaar \\ Marcel P. Timmer \\ Working Paper 24292 \\ http://www.nber.org/papers/w24292
}

\author{
NATIONAL BUREAU OF ECONOMIC RESEARCH \\ 1050 Massachusetts Avenue \\ Cambridge, MA 02138 \\ February 2018
}

We thank the NSF (US), SSHRC (Canada), and NWO (Netherlands) for their financial support under a Digging into Data grant of the Trans-Atlantic Platform, entitled "Online Prices for Computing Standards Of Living across Countries (OPSLAC)", https://diggingintodata.org/ awards/2016/project/online-prices-computing-standards-living-across-countries-opslac. We also thank the International Comparisons Program and PriceStats for sharing their data and expertise. The views expressed herein are those of the authors and do not necessarily reflect the views of the National Bureau of Economic Research.

At least one co-author has disclosed a financial relationship of potential relevance for this research. Further information is available online at http://www.nber.org/papers/w24292.ack

NBER working papers are circulated for discussion and comment purposes. They have not been peer-reviewed or been subject to the review by the NBER Board of Directors that accompanies official NBER publications.

(C) 2018 by Alberto Cavallo, W. Erwin Diewert, Robert C. Feenstra, Robert Inklaar, and Marcel P. Timmer. All rights reserved. Short sections of text, not to exceed two paragraphs, may be quoted without explicit permission provided that full credit, including $\odot$ notice, is given to the source. 
Using Online Prices for Measuring Real Consumption Across Countries

Alberto Cavallo, W. Erwin Diewert, Robert C. Feenstra, Robert Inklaar, and Marcel P. Timmer

NBER Working Paper No. 24292

February 2018

JEL No. E3,E31,F0,F41,O47

\title{
ABSTRACT
}

We show that online prices can be used to construct quarterly purchasing power parities (PPPs) with a closely-matched set of goods and identical methodologies in a variety of developed and developing countries. Our results are close to those reported by the International Comparisons Program (ICP) in 2011 and the OECD in 2014, and can be used to obtain more up-to-date estimates of real consumption across countries without the need for consumer price index extrapolations. We discuss advantages and limitations associated with the use of online prices for PPs, including issues of representativeness and limited coverage of product categories and countries.

\author{
Alberto Cavallo \\ Robert Inklaar \\ MIT Sloan School of Management \\ University of Groningen \\ 100 Main Street, E62-512 \\ Cambridge, MA 02142 \\ Faculty of Economics \\ and NBER \\ PO Box 800 \\ acavallo@mit.edu \\ 9700 AV Groningen \\ The Netherlands \\ R.C.Inklaar@rug.nl \\ W. Erwin Diewert \\ Department of Economics \\ Marcel P. Timmer \\ University of British Columbia \\ University of Groningen \\ \#997-1873 East Mall \\ Vancouver, BC V6T 1Z1 \\ 9700 AB Groningen \\ CANADA \\ The Netherlands \\ and NBER \\ m.p.timmer@rug.nl \\ erwin.diewert@ubc.ca \\ Robert C. Feenstra \\ Department of Economics \\ University of California, Davis \\ One Shields Avenue \\ Davis, CA 95616 \\ and NBER \\ rcfeenstra@ucdavis.edu
}




\section{Using Online Prices for Measuring Real Consumption Across Countries \\ By Alberto Cavallo, W. Erwin Diewert, Robert C. \\ FEENSTRA, ROBERT INKLAAR AND MARCEL P. TIMMER*}

International income comparisons such as the Penn World Table (PWT) rely on data provided by the International Comparisons Program (ICP) at the World Bank, which collects prices from thousands of comparable goods and services all over the world to calculate purchasing power parities (PPPs). While ICP continually improves its methods, its reliance on traditional data collection through National Statistical Offices (NSOs) causes many problems, including the low frequency of data collection (every 6 years), long delays in publication (results for the 2011 round were published in 2014), issues affecting the comparability of products and methods across countries and time (see e.g. Deaton and Heston (2010), Inklaar and Rao (2017)), as well as the need to rely on the efforts of individual countries that can refuse to participate (e.g. Argentina for ICP 2011) or lack transparency regarding their data and methods (see Feenstra et al. (2013)).

The availability of new (big) data sources provides hope for improvements along several of these dimensions. In particular, we show that online prices can be used to construct quarterly PPPs published in real-time, with a closely-matched basket of goods and identical methodologies in a variety of developed and developing economies. At a more fundamental level, the ability to remotely collect online prices provides more control and transparency to the data and methodologies used to compute PPPs across countries.

Our data cover eleven countries in three major consumption categories, Food and Beverages, Fuel, and Electronics, from 2011 to 2017. In a validation exercise, we find that PPPs constructed

\footnotetext{
* Cavallo: Massachusetts Institute of Technology, 77 Mass Ave, Cambridge MA 02138, USA (email: acavallo@mit.edu); Diewert: University of British Columbia, 2329 West Mall, Vancouver, BC V6T1Z4, Canada (email: erwin.diewert@ubc.ca); Feenstra: University of California - Davis, One Shields Ave, Davis, CA 95616, USA (email:rcfeenstra@ucdavis.edu); Inklaar: University of Groningen, Nettelbosje 2, Groningen 9747AE, Netherlands (email: r.c.inklaar@rug.nl); Timmer: University of Groningen, Nettelbosje 2, Groningen 9747AE, Netherlands (email: m.p.timmer@rug.nl). Acknowledgments: We thank the NSF (US), SSHRC (Canada), and NWO (Netherlands) for their financial support under a Digging into Data grant of the Trans-Atlantic Platform, entitled “Online Prices for Computing Standards Of Living across Countries (OPSLAC)”, https://diggingintodata.org/awards/2016/project/online-prices-computing-standards-living-across-countries-opslac. We also thank the International Comparisons Program and PriceStats for sharing their data and expertise.
} 
with online prices are close to those reported by ICP in 2011 and the OECD in 2014. Next, we illustrate the potential of the new data to provide quarterly estimates of real consumption across countries for the fourth quarter of 2017.

While promising, we also highlight many potential problems associated with the use of online prices for PPP calculations, including the lack of representativeness and limited coverage of product categories and countries.

\section{Data and Methodology}

We use micro data available at the Billion Prices Project (BPP) at MIT, including daily webscraped prices from 2010 to 2017 for all products sold by some of the largest multi-channel retailers in eleven countries: Argentina, Australia, Brazil, China, Canada, Netherlands, Germany, Japan, South Africa, the United Kingdom, and the United States. ${ }^{2}$ These prices include taxes and exclude shipping costs. ${ }^{3}$

In constructing price comparisons across countries, one is confronted with the challenge of matching products and comparing "like-with-like”. Product codes that are attached to the online goods cannot be used because they tend to be retailer or county-specific. Moreover, identical products are seldom available across countries, except for global branded products, which constitute a relatively minor share of expenditures. So to ensure sufficient coverage, local goods have to be grouped before matching is possible.

We therefore mimic the procedures followed by ICP 2011, starting with the creation of our own list of "items" (narrowly-defined product categories) to which individual products will be matched. ${ }^{4}$ Our item list consists of 267 narrow definitions that cover all subsectors of the UN's COICOP classification system for Food and Beverages, Fuel, and Electronics. ${ }^{5}$ This is slightly higher than the number of items for these categories in ICP 2011, as shown in Table 1.

\footnotetext{
2 The data were collected by PriceStats, a private company associated with the BPP, which also matched the products for 9 of the 11 countries in our sample. See Cavallo and Rigobon (2016) for details on the data and methodologies. Alberto Cavallo is a co-founder of both the BPP and PriceStats.

${ }^{3}$ For countries where the sales tax is not included in prices shown to customers online, we add a standard sales or VAR tax to scraped prices as follows: US Food 0.952\%, Electronics 5.08\%. Japan Food and Electronics 5\% before 3/2014 and 8\% afterwards; Germany Food "7\% and Electronics 19\%; Canada Electronics, Chocolates and Sodas 12\%. The Canadian average is computed from state-level rates weighted by state population

${ }^{4}$ See World Bank (2014) for a description of ICP methodologies, and World Bank (2013) for an extensive motivation of why these methods are applied.

5 See https://unstats.un.org/unsd/cr/registry/regcst.asp?Cl=5. Our "Food and Beverages" sector corresponds to COICOP code 01, the "Fuel” sector is COICOP 07.2.2, and "Electronics" covers COICOP codes 09.1.1 to 09.1.4.
} 
TABLE 1 -DATA SOURCE COMPARISON

\begin{tabular}{lcc}
\hline \hline $\begin{array}{l}\text { For Food, Fuel, and } \\
\text { Electronics* }\end{array}$ & BPP (2017) & ICP (2011) \\
\hline $\begin{array}{l}\text { Data collection } \\
\text { Publication frequency }\end{array}$ & Daily & $\begin{array}{c}\text { Within a year } \\
\text { Quarterly years (3 years for } \\
\text { OECD) }\end{array}$ \\
Number of items & 267 & 238 \\
$\begin{array}{l}\text { Products per } \\
\text { country (mean) }\end{array}$ & 30 & $10-15$ homogeneous** \\
item- & Goods & $70-100$ heterogeneous \\
Lype of coverage & Urban & Goods \& Services \\
Countries & 11 & Urban \& Rural \\
\hline
\end{tabular}

Notes: *Includes only COICOP codes for Food and Beverages (01), Fuel (07.2.2), and Electronics (From 09.1.1 to 09.1.4) **Estimates in World Bank (2013). Source: Authors’ calculations based on World Bank (2013)

These items were chosen to strike a balance between comparability and representativeness. We have a mix of narrowly-defined global products (e.g. "Decaf Ground Illy Coffee”) and broader item definitions for unbranded products or local brands (e.g. "Basmati Rice” or "Decaf Ground Coffee, all other brands”). Our item definitions tend to be more narrowly defined than those in ICP's 2011 list, particularly in electronics. ${ }^{6}$

The matching of individual products to each item definition is a labor-intensive process. The micro data contains detailed descriptions for millions of products. Searching this database, we find those products that best match the item descriptions in each country, and enter their package sizes so that we can calculate unit prices (e.g. price per gram). A total of 99,028 individual products were matched, with a mean of 30 products per item in each country. We concentrated our matching efforts in recent years, when the micro data become more abundant, so our coverage of consumer expenditures improves considerably after 2012.

\footnotetext{
6 See Table A2 in the Appendix for more examples and some item counts by product category.
} 
FIGURE 1: SHARE OF BASIC HEADINGS COVERED BY MATCHED BPP DATA

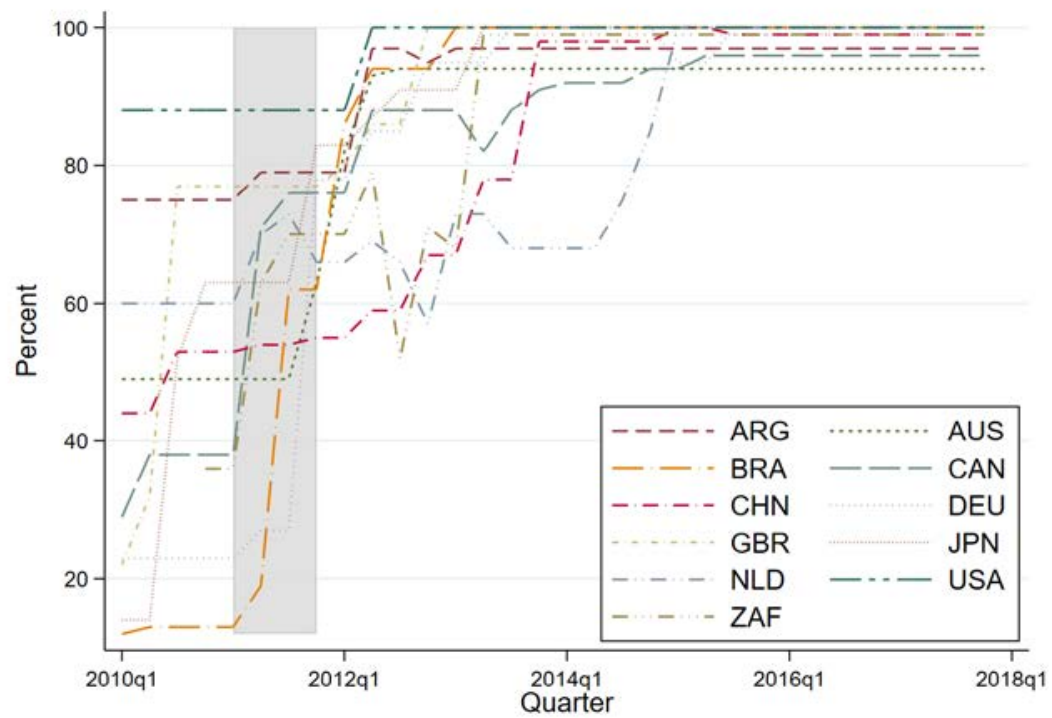

Note: Share of all basic headings in ICP food, fuel, and electronics categories. 2011 quarters shaded in gray.

Once the individual products are matched, we average all unit-price observations (across products and time) for each item, country, and quarter, implicitly assigning more weight to those products that are available to consumers for a longer time within the quarter. Average prices are then aggregated to the level of a "basic heading”, such as 'Rice' or 'Coffee, Tea, and Cocoa'. Not all items within each basic heading are priced in every country, so we follow ICP and run a Country Product Dummy (CPD) regression for every quarter and every basic heading $k$ :

$$
\log p_{i j}^{k}=\eta_{i}^{k}+\eta_{j}^{k}+\epsilon_{i j}^{k}
$$

Where the price of item $i$ in country $j$ is regressed on item dummies $\eta_{i}$ and country dummies $\eta_{j}$. The exponent of each country dummy is the estimated PPP for a particular basic heading, $P_{k j}=$ $\exp \left(\eta_{j}^{k}\right) \cdot{ }^{7}$

We use the expenditure data from ICP 2011 for further aggregation using a multilateral GEKS methodology. Let $s_{k j}$ be the expenditure share of basic heading $k$ in total consumption, then we

\footnotetext{
7 The country dummy for the reference country (in our case the United States) is omitted, so $P_{k U S A}=1$
} 
can define the Laspeyres index $P_{j b}^{L}=\sum_{k} s_{k b} P_{k j} / P_{k b}$ using expenditure shares in the reference country $b$, the Paasche index $P_{j b}^{P}=\left(\sum_{k} s_{k j} P_{k b} / P_{k j}\right)^{-1}$ using country $j$ expenditure shares, and the Fisher index as the geometric mean: $P_{j b}^{F}=\left(P_{j b}^{L} \times P_{j b}^{P}\right)^{\frac{1}{2}}$. To obtain a reference-country independent PPP, we further compute a GEKS index for all $M$ countries:

$$
P_{j}^{G E K S}=\left(\prod_{b}^{M} P_{1 b}^{F} P_{b j}^{F}\right)^{\frac{1}{M}}
$$

PPPs are expressed as national currency per unit of the base country (in our case the US dollar). To ease interpretation to facilitate the comparison across countries and samples, we also compute price level indices (PLIs), dividing the PPPs by the country's nominal exchange rate with the US dollar. PLIs are unit-free and reflect whether prices are higher $(>1)$ or lower $(<1)$ relative to the reference country.

\section{Comparison to ICP}

We now compare our PLIs with those of ICP for 2011, the most recent global price comparison. In principle, there are many reasons to expect differences. First, our prices are collected online for large branded retailers selling in mostly urban locations, while ICP data is collected in physical stores in many kinds of retailers and geographical locations. Second, online prices are collected every day, while ICP prices are obtained once (or a few times) per year. Temporal aggregation obscures the comparison because PPPs can vary significantly within a year (particularly in high inflation countries). Third, there are methodological details in ICP that we cannot replicate. This includes the use of an "importance" weight for each item in the CPD regression, as quantity weights are only available at the basic heading level.

Despite these differences, Figure 2 shows that PLIs computed with online data align well with those calculated from ICP data (US = 1). These are results for grouped items within Food, Fuel and Electronics, using basic heading expenditure weights (see Appendix Figure 1 for comparisons at basic heading level). The PLIs are closest for Fuel, where the item definitions are identical across ICP and BPP. In Food and Electronics there is more dispersion but no evidence of PLIs being consistently higher or lower with online data. 
FIGURE 2. BPP VS ICP PRICE LEVEL INDEXES - 2011

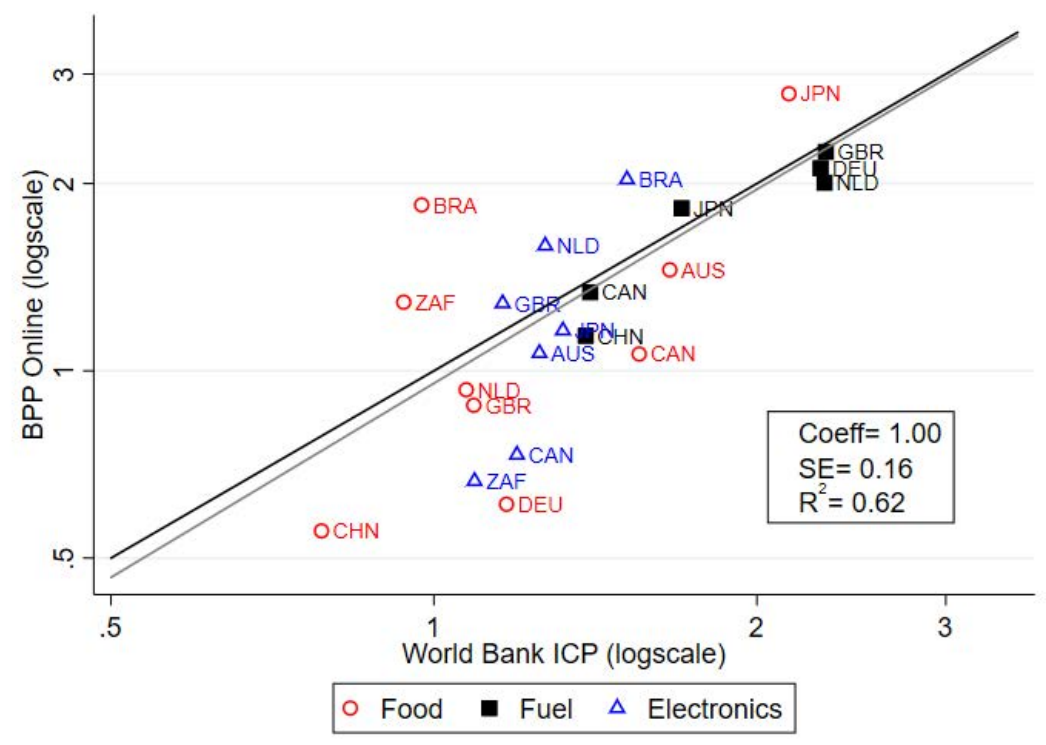

Note: Comparison of the ICP 2011 and BPP bilateral Fisher indices at the sector level for each country. 45-degree line in black, linear fit line in gray. All axes on log scale.

Multilateral PLIs for each country are compared in Table 1. On average, online and ICP PLIs for 2011 differ by 15\% in absolute value across the eleven countries. In some cases, such as Australia, the results are nearly identical, while in others, such as Japan, the difference is as high as $28 \%$.

We repeat the comparison in 2014 for OECD countries, for which PPPs are published every three years. The average difference is much smaller in this case, likely because our coverage of basic headings with online prices is nearly complete at this time. ${ }^{8}$

${ }^{8}$ See Appendix Figure A1 for basic heading coverage in every country over time. 
TABLE 1- MUltilateral PRICE LEVEL INDEX (PLI=PPP/E), USA=1

\begin{tabular}{lcccc}
\hline \hline & & & & 2014 \\
& BPP & ICP & BPP & OECD \\
\hline Argentina & 0.79 & - & 1.05 & - \\
Australia & 1.52 & 1.53 & 1.24 & 1.36 \\
Brazil & 1.44 & 1.20 & 1.17 & - \\
Canada & 1.08 & 1.30 & 1.15 & 1.29 \\
China & 0.71 & 0.93 & 0.97 & - \\
Germany & 1.12 & 1.30 & 1.20 & 1.35 \\
Japan & 2.57 & 2.01 & 1.58 & 1.42 \\
Netherlands & 1.21 & 1.29 & 1.22 & 1.27 \\
South Africa & 1.11 & 0.96 & 0.91 & - \\
United Kingdom & 1.14 & 1.25 & 1.26 & 1.37 \\
United States & 1.00 & 1.00 & 1.00 & 1.00 \\
\hline Mean Absolute Difference & & & & \\
All countries & & $15 \%$ & & $9 \%$ \\
OECD & & $17 \%$ & & \\
\hline
\end{tabular}

Notes: Multilateral GEKS PLIs covering all basic headings available in Food, Fuel, and Electronics. BPP numbers are yearly averages from quarterly PLIs excluding those quarters for which there are less than $50 \%$ of basic headings covered. No ICP data is available for Argentina in 2011 because the country refused to participate.

Beyond the comparison with ICP, a major advantage of using online data to measure PPPs is that we can provide more frequent and timely estimates of real consumption across countries. For example, the first column in Table 2 shows a cross-country comparison of the real household consumption of Food, Fuel and Electronics for the last quarter of 2017.

TABLE 2 - REAL HOUSEHOLD CONSUMPTION PER CAPITA OF FOOD, FUEL AND ELECTRONICS BASED ON BPP DATA FOR 2017Q4 (USA=1)

\begin{tabular}{lcc}
\hline \hline & Actual & $\begin{array}{c}\text { Extrapolated with } \\
\text { CPIs }\end{array}$ \\
\hline Argentina & \multicolumn{2}{c}{0.70} \\
Australia & 0.41 & 0.74 \\
Brazil & 0.76 & 0.22 \\
Canada & 0.20 & 0.89 \\
China & 0.61 & 0.18 \\
Germany & 0.11 & 0.76 \\
Japan & 0.60 & 0.40 \\
Netherlands & 0.45 & 0.70 \\
South Africa & 0.57 & 0.20 \\
United Kingdom & 0.18 & 0.76 \\
United States & 0.72 & 1.00 \\
\hline
\end{tabular}

Sources: Total household consumption expenditure in local currency units, total population, the consumer price index and the exchange relative to the US dollar is taken from the OECD Main Economic Outlook, no. 102 (November 2017). For China, household consumption expenditure is from the UN National Accounts Official Country Data for 2015, extrapolated to 2017 using the growth of GDP at constant prices and the consumer inflation rate for 2016 and 2017 from the IMF World Economic Outlook of October 2017. The share of food, fuel and electronics in total household consumption is from ICP 2011.

Notes: 'Extrapolated' figures are based on the 2011 BPP price level index, extrapolated to 2017Q4 using the difference in (overall) consumer price inflation from 2011 to 2017Q4 between each country and the United States minus the change in the exchange rate. Estimates of for Argentina, Brazil, China and South Africa are for 2017 as a whole, rather than the fourth quarter of 2017. The 'Actual' figures are based on the BPP prices for 2017Q4. 
The measurement of PPPs on a quarterly basis can replace current nowcasting procedures that rely on extrapolation of benchmark PPPs with relative CPI movements. These extrapolations are prone to cause biases that distort the PLIs (Deaton and Aten (2017)). In fact, online PPPs could help avoid extrapolation "surprises”, particularly in countries where CPI data and methods do not match well with the ICP comparisons framework. Comparing column 2 (based on extrapolated 2011 PPPs) with column 1 reveals that these surprises can be large and occasionally more than 50 percent (as for China, Argentina and Canada).

\section{Limitations}

While helpful, online data have many limitations. First, given that prices are mostly from large retailers with an online presence, the resulting PPPs may not be representative for national averages, especially in countries with a fragmented retail sector or (for Food) where the local diet relies heavily on regional products. Furthermore, the prices in websites of these retailers can be different from the prices found in their physical stores, where most retail transactions take place (at least for now). Cavallo (2017) shows these differences are small on average, but they could still meaningfully affect price-level comparisons in some countries. ${ }^{9}$

Second, most retailers that sell online tend to have a single price for all locations within a country. This seems at odds with existing ICP data that shows significant regional price dispersion (such as urban areas having higher prices of food, especially in poorer countries). ${ }^{10}$ This lack of spatial price differences can be resolved by scraping more localized retailers, whose online presence is improving over time.

Third, online data do not have expenditure weights for individual products, so it is hard to know which products are more important for the comparison. In ICP this is decided upon by the NSO data collectors, who arguably have more information to make the choice. While scanner or other expenditure data sources could potentially be used as a complement in some categories, the question of which matched individual products are more representative of actual consumption remains.

\footnotetext{
9 To control for persistent online-offline differences, ICP can periodically estimate an average difference and adjust local prices accordingly. See Cavallo (2017) for a discussion.

10 Some of this price dispersion could be explained by data collected from different retailers, as there is growing evidence that firms use uniform pricing policies within countries. See DellaVigna \& Gentzkow (2017) for the US, and Cavallo (2017) for some other countries.
} 
Fourth, online data only cover a limited number of product categories and countries. The three sectors included in this paper represent only between $13 \%$ and $23 \%$ of the share of household consumption in these countries. While more categories with online prices can be potentially added, there are hard-to-compare areas of consumption, such as housing, personal services or health services, that will likely remain a challenge until more data are available online. Similarly, online prices are currently available in a small number of countries. We have matched data in 11 countries out of approximately 60 for which the BPP has some price information. While matching can improve, our approach is not yet viable in countries where there is still little price data online.

\section{Conclusions}

We have shown that online prices can be used to enhance ICP data, dramatically improving the frequency and transparency of PPPs compared with traditional data collection methods. We have also identified many challenges and limitations of online data.

We further note that the process of selecting ("matching') products across countries remains a challenge, even with "Big Data”. Online data enlarge the universe of products from which comparable goods are chosen, and potentially improve the transparency and similarity in methods used across countries, but selecting individual goods continues to be a labor-intensive task that cannot be easily performed by automated procedures due to the lack of standardization in product identification numbers and descriptions.

Future work could address some of these issues, as well as explore other potential uses of online prices in the context of PPP measurement, such as the computations of standard errors for national average prices, the use of retailer dummies and other product characteristics in CPD regressions, and better ways to account for entering and exiting products and items across countries. 


\section{REFERENCES}

Cavallo, A. and R. Rigobon (2016), “The Billion Prices Project: Using Online Prices for Inflation Measurement and Research” Journal of Economic Perspectives 30 (2): 151-78.

Cavallo, A. (2017), “Are Online and Offline Prices Similar? Evidence from Multi-Channel Retailers” American Economic Review 107 (1), 283-303.

Deaton, Angus and Alan Heston (2010), ‘Understanding PPPs and PPP-based National Accounts’ American Economic Journal: Macroeconomics, 2: 1-35.

Deaton, Angus and Bettina Aten (2017) “Trying to Understand the PPPs in ICP2011: Why are the Results so Different?” American Economic Journal: Macroeconomics, 9(1): 243-64

DellaVigna \& Gentzkow (2017)?

Feenstra, Robert C., Hong Ma, J. Peter Neary and D. S. Prasada Rao (2013) "Who Shrunk China? Puzzles in the Measurement of Real GDP” Economic Journal 123(573): 1100-1129.

Inklaar, Robert and D.S. Prasada Rao (2017). 'Cross-Country Income Levels over Time: Did the Developing World Suddenly Become Much Richer?' American Economic Journal: Macroeconomics 9(1): 265-290.

World Bank (2013), Measuring the real size of the world economy. The framework, methodology, and results of the International Comparison Program-ICP, World Bank: Washington DC.

World Bank (2014), Purchasing Power Parities and Real Expenditures of World Economies Summary of Results and Findings of the 2011 International Comparison Program World Bank: Washington DC. 


\title{
APPENDIX
}

\section{Using Online Prices for Measuring Real Consumption Across Countries}

\author{
By Alberto Cavallo, W. Erwin Diewert, Robert C.
}

FEENSTRA, ROBERT INKLAAR AND MARCEL P. TIMMER*

FIGURE A1. BASIC HEADING COMPARISON ICP VS BPP FOR 2011

PANEL A: ONLINE PPP IS AN ANNUAL AVERAGE

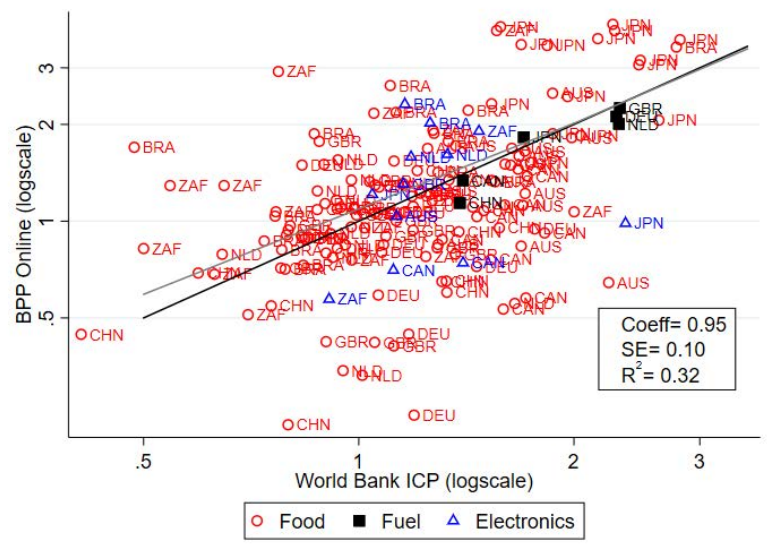

PANEL B: ONLINE PPP FROM QUARTER WITH SMALLEST DIFFERENCE

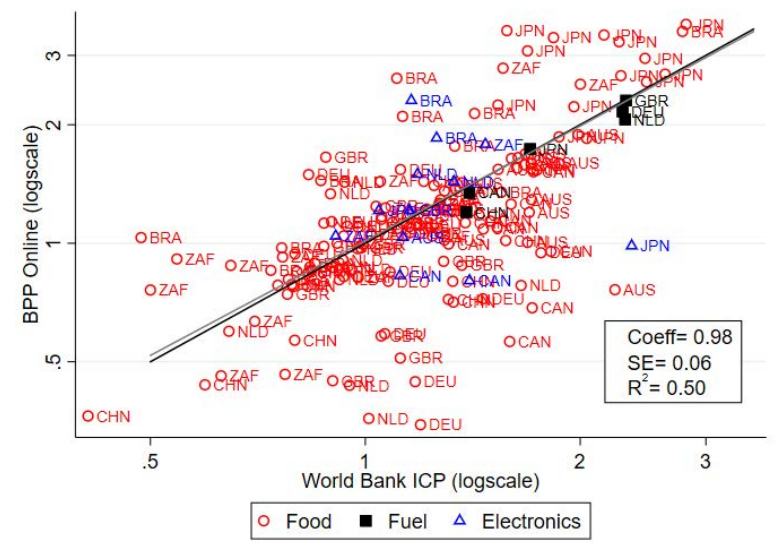


TABLE A1—ITEM LIST COMPARISON

\begin{tabular}{|c|c|c|c|c|}
\hline \multirow[t]{2}{*}{ Basic Heading } & \multicolumn{2}{|c|}{ Number of Items } & \multicolumn{2}{|l|}{ Item Examples } \\
\hline & BPP & ICP & BPP & ICP \\
\hline Rice & 4 & 9 & $\begin{array}{l}\text { White Rice, All Brands, Basmati } \\
\text { White Rice, All Brands, Long-grain }\end{array}$ & $\begin{array}{l}\text { Basmati Rice } \\
\text { Long-grain rice - Family Pack }\end{array}$ \\
\hline $\begin{array}{l}\text { Other cereals, } \\
\text { flour and other } \\
\text { products }\end{array}$ & 12 & 6 & $\begin{array}{l}\text { All-purpose Flour, All Brands, Wheat } \\
\text { All-purpose Flour, All Brands, All Other } \\
\text { Cereal for Breakfast, Kellogg's, All Other }\end{array}$ & $\begin{array}{l}\text { Wheat flour, not self-rising } \\
\text { Wheat flour, not self-rising } \\
\text { Cornflakes (Kellogg's) }\end{array}$ \\
\hline Pasta & 7 & 6 & $\begin{array}{l}\text { Pasta, All Brands, Spaghetti } \\
\text { Pasta, Barilla, Penne (including whole grain) }\end{array}$ & $\begin{array}{l}\text { Spaghetti } \\
\text { Short Pasta }\end{array}$ \\
\hline Beef and Veal & 2 & 8 & $\begin{array}{l}\text { Beef, All Brands, Tenderloin roast or steak } \\
\text { Beef, All Brands, Ground }\end{array}$ & $\begin{array}{l}\text { Beef, fillet } \\
100 \% \text { Beef, minced }\end{array}$ \\
\hline Poultry & 1 & 6 & Chicken, All Brands, Breasts & Chicken breast without skin \\
\hline $\begin{array}{l}\text { Fresh, chilled or } \\
\text { frozen sea food }\end{array}$ & 2 & 13 & $\begin{array}{l}\text { Shrimp, All Brands, Fresh Uncooked } \\
\text { Shrimp, All Brands, Frozen Uncooked }\end{array}$ & $\begin{array}{l}\text { Whole Shrimps } \\
\text { Shrimps }\end{array}$ \\
\hline $\begin{array}{l}\text { Preserved or } \\
\text { processed fish } \\
\text { and seafood }\end{array}$ & 4 & 5 & $\begin{array}{l}\text { Canned Tuna, All Brands, In Oil } \\
\text { Canned Tuna, All Brands, In water } \\
\text { Canned Tuna, All Brands, All Other }\end{array}$ & $\begin{array}{l}\text { Canned Tuna without skin } \\
\text { Canned Tuna without skin } \\
\text { Canned Tuna without skin }\end{array}$ \\
\hline Cheese & 7 & 6 & $\begin{array}{l}\text { Cream Cheese, Philadelphia, Regular } \\
\text { Cream Cheese, Philadelphia, Fat free, low fat } \\
\text { Cream Cheese, Philadelphia, All Other }\end{array}$ & $\begin{array}{l}\text { Cream Cheese } \\
\text { Cream Cheese } \\
\text { Cream Cheese }\end{array}$ \\
\hline $\begin{array}{l}\text { Eggs and egg- } \\
\text { based products }\end{array}$ & 1 & 2 & $\begin{array}{l}\text { Eggs, All Brands, Chicken } \\
\text { Eggs, All Brands, Chicken }\end{array}$ & $\begin{array}{l}\text { Large Size Chicken Eggs } \\
\text { Medium Size Chicken Eggs }\end{array}$ \\
\hline $\begin{array}{l}\text { Butter and } \\
\text { margarine }\end{array}$ & 3 & 3 & $\begin{array}{l}\text { Butter, All Brands, Salted } \\
\text { Butter, All Brands, All Other }\end{array}$ & $\begin{array}{l}\text { Salted Butter } \\
\text { Butter, unsalted }\end{array}$ \\
\hline $\begin{array}{l}\text { Other edible oils } \\
\text { and fats }\end{array}$ & 6 & 6 & Olive Oil, All Brands, Extra Virgin & Olive Oil \\
\hline $\begin{array}{l}\text { Fresh or chilled } \\
\text { fruits }\end{array}$ & 7 & 13 & Apples, All Brands, Red & Apple, Red Delicious \\
\hline $\begin{array}{l}\text { Fresh or chilled } \\
\text { vegetables }\end{array}$ & 5 & 15 & $\begin{array}{l}\text { Onions, All Brands, White, Yellow or Brown } \\
\text { Onions, All Brands, Red }\end{array}$ & $\begin{array}{l}\text { Onion } \\
\text { Onion }\end{array}$ \\
\hline Food Products & 17 & 13 & $\begin{array}{l}\text { Ketchup, Heinz, Regular } \\
\text { Ketchup, All Brands, Regular } \\
\text { Ketchup, All Brands, All Other } \\
\text { Ketchup, All Brands, Reduced Sodium/Sugar }\end{array}$ & $\begin{array}{l}\text { Tomato Ketchup } \\
\text { Tomato Ketchup } \\
\text { Tomato Ketchup } \\
\text { Tomato Ketchup }\end{array}$ \\
\hline $\begin{array}{l}\text { Coffee, Tea and } \\
\text { Cocoa }\end{array}$ & 16 & 7 & $\begin{array}{l}\text { Chocolate Powder, Nesquick, Regular } \\
\text { Chocolate Powder, Nesquick, All Other } \\
\text { Coffee, All Brands, Ground (Excluding decaf.) } \\
\text { Coffee, All Brands, Ground (Excluding decaf.) } \\
\text { Coffee, Illy, Ground (including decaf) }\end{array}$ & $\begin{array}{l}\text { Cocoa Powder, Tin } \\
\text { Cocoa Powder, Tin } \\
\text { Coffee Roasted } 100 \% \text { Arabica } \\
\text { Coffee Roasted } 100 \% \text { Robusta } \\
\text { Instant Coffee, Nescafe Classic }\end{array}$ \\
\hline $\begin{array}{l}\text { Mineral Waters, } \\
\text { Soft drinks and } \\
\text { vegetable Juices }\end{array}$ & 35 & 6 & $\begin{array}{l}\text { Sodas, Coca Cola, Classic or Regular } \\
\text { Sodas, Pepsi, Classic or Regular } \\
\text { Mineral Water, All Brands, Still } \\
\text { Mineral Water, Evian } \\
\text { Mineral Water, Fiji }\end{array}$ & $\begin{array}{l}\text { Coca-Cola/Pepsi, Large } \\
\text { Coca-Cola/Pepsi, Large } \\
\text { Mineral Water } \\
\text { Mineral Water } \\
\text { Mineral Water }\end{array}$ \\
\hline $\begin{array}{l}\text { Audio-visual, } \\
\text { photographic and } \\
\text { information } \\
\text { processing } \\
\text { equipment }\end{array}$ & 82 & 27 & $\begin{array}{l}\text { Laptop, Apple, MacBook, } 13 \text { inch } \\
\text { Laptop, Acer, 14-16 inch } \\
\text { Television, Phillips, LED 32" } \\
\text { Television, Samsung, LED 32" } \\
\text { Television, All Brands, LED 32" } \\
\text { Television, LED, 40-43", LG } \\
\text { Camera Compact, Canon, 20-24mpx } \\
\text { Camera Compact, Nikon, 20-24mpx } \\
\text { Camera Compact, Sony, 20-24mpx }\end{array}$ & $\begin{array}{l}\text { Apple MacBook laptop computer } \\
\text { Acer Aspire One netbook } \\
\text { Phillips } 3000 \text { series LCD TV 32" } \\
\text { Samsung Series } 5 \text { LCD TV } \\
32 \text { Inches LCD Television } \\
\text { LG LD Series LCD TV 42" } \\
\text { Digital Compact Camera } \\
\text { Digital Compact Camera } \\
\text { Digital Compact Camera }\end{array}$ \\
\hline $\begin{array}{l}\text { Fuels and } \\
\text { lubricants for } \\
\text { personal transport } \\
\text { equipment }\end{array}$ & 4 & 5 & $\begin{array}{l}\text { Petrol, All Brands, Low RON } \\
\text { Petrol, All Brands, Medium RON } \\
\text { Petrol, All Brands, High RON } \\
\text { Diesel }\end{array}$ & $\begin{array}{l}\text { Petrol } \\
\text { Petrol, Super } \\
\text { Petrol, Superplus } \\
\text { Diesel fuel }\end{array}$ \\
\hline
\end{tabular}

Source: Authors’ calculations based on BPP and ICP 2011 data. 